\title{
PENGARUH POLA ASUH ORANG TUA OTORITER DAN AKTIVITAS \\ SOSIAL TERHADAP KEMAMPUAN MENGATASI MASALAH \\ BELAJAR PADA SISWA KELAS VI SDN KRATON 2 MAOSPATI TAHUN PELAJARAN 2010/2011
}

\author{
Indah Wahyu Yuliani dan Dahlia Novarianing Asri*
}

\begin{abstract}
Abstrak
Penelitian ini bertujuan untuk mengetahui (1) pengaruh pola asuh orang tua otoriter terhadap kemampuan mengatasi masalah belajar pada siswa kelas VI SDN Kraton 2 Maospati; (2) pengaruh tingkat aktivitas sosial siswa terhadap kemampuan mengatasi masalah belajar pada siswa kelas VI SDN Kraton 2 Maospati; (3) pengaruh pola asuh orang tua otoriter dan tingkat aktivitas sosial siswa secara simultan terhadap kemampuan mengatasi masalah belajar pada siswa kelas VI SDN Kraton 2 Maospati.

Populasi penelitian adalah siswa kelas VI SDN Kraton 2 Maospati tahun pelajaran 2010/2011. Sampel penelitian menggunakan teknik total sampling dengan jumlah populasi 31 siswa. Pengumpulan data menggunakan metode angket. Analisis data menggunakan teknik statistik dengan menggunakan rumus korelasi berganda dan untuk mengetahui signifikansi pengaruh antar variabel digunakan uji-F.

Berdasarkan analisis data dapat disimpulkan sebagai berikut: (1) ada pengaruh yang signifikan dan negatif antara pola asuh orang tua otoriter terhadap kemampuan siswa mengatasi masalah belajar pada siswa kelas VI SDN Kraton 2 Maospati tahun pelajaran 2010/2011, (2) ada pengaruh signifikan dan positif antara aktivitas sosial siswa terhadap kemampuan siswa mengatasi masalah belajar pada siswa kelas VI SDN Kraton 2 Maospati tahun pelajaran 2010/2011, dan (3) ada pengaruh signifikan dan positif antara pola asuh orang tua otoriter bersama dengan aktivitas sosial siswa secara simultan terhadap kemampuan siswa mengatasi masalah belajar pada siswa kelas VI SDN Kraton 2 Maospati tahun pelajaran 2010/2011.
\end{abstract}

Kata Kunci: Pola Asuh Orang Tua Otoriter, Aktivitas Sosial, Kemampuan Mengatasi Masalah Belajar

* Indah Wahyu Yulianti adalah mahasiswa Program Studi Bimbingan dan Konseling Fakultas Ilmu Pendidikan IKIP PGRI Madiun

Dahlia Novarianing Asri adalah Dosen Program Studi Bimbingan dan Konseling Fakultas Ilmu Pendidikan IKIP PGRI Madiun 


\section{Pendahuluan}

Masalah-masalah yang
dialami seorang siswa pada awal
perkembangannya bisa jadi sangat
kompleks, di antaranya adalah
masalah belajar. Faktor yang
mempengaruhi masalah belajar
berasal dari dalam diri siswa seperti
intelegensi yang rendah (slow
learner), sikap dan kebiasaan belajar
yang kurang baik, serta minat dan
bakat yang tidak sesuai maupun dari
luar diri siswa seperti faktor
keluarga, sekolah dan lingkungan
masyarakat (Kardi, 2006:74).

Dengan demikian,

kemampuan siswa dalam mengatasi

masalah belajar sangat penting

artinya apabila kemampuan ini tidak

dikuasai oleh siswa dapat

menimbulkan akibat yang fatal.

Contohnya adalah kasus seorang

pelajar SMP di Purworejo yang nekat mengakhiri hidupnya karena takut

tidak lulus ujian nasional (Heri Pranoto, 2010). Perilaku dengan skala lebih kecil seperti siswa menjadi depresi, takut terhadap respon orang tua, serta menarik diri dari hubungan sosial juga nampak terjadi pada siswa kelas VI SDN Kraton 2 Kecamatan Maospati Kabupaten Magetan.

Kemampuan mengatasi masalah seseorang tergantung pada respon yang timbul saat menghadapi masalah. Cara individu untuk menghadapi masalah ini disebut strategi mengatasi masalah (Coping Behavior). Faktor-faktor yang menentukan keberhasilan mengatasi masalah seorang individu antara lain dukungan keluarga dan keterampilan dalam bersosialisasi atau aktivitas sosial di lingkungannya (Fatchiah, 2009:32). 
Keluarga sebagai tempat kepribadian manusia itu sendiri belajar sangat menentukan dalam hal $\quad$ (Vitalis Djarot Sumarwoto, 2008:8).

timbulnya masalah belajar pada anak didik. Orang tua yang bersifat kejam, otoriter dan lebih mementingkan harga diri daripada memberikan anaknya kesempatan untuk mengambil keputusan sendiri, akan menyebabkan tekanan mental pada anak. Sedangkan sebagai makhluk sosial, setiap individu dalam perkembangannya memerlukan kerjasama dan interaksi sosial dengan orang lain. Manusia mengadakan interaksi sosial guna saling menumbuh dan kembangkan, saling mempengaruhi, saling memberi dan menerima, saling mencintai dan dicintai, dan saling membangun (konstruktif), serta menghindari kehancuran (destruktif), terutama dalam pengembangan

$$
\text { Dari pernyataan tersebut, }
$$
jelaslah bahwa dukungan keluarga dan aktivitas sosial seorang siswa dapat meningkatkan taraf perkembangan kepribadian siswa menjadi lebih matang yang ditandai dengan meningkatnya kemampuan mengatasi masalah-masalah belajar yang sedang dihadapi melalui strategi mengatasi masalah yang tepat.

Berdasarkan hasil penelitian terdahulu ditemukan bahwa pola asuh orang tua yang otoriter dan aktivitas sosial sangat berpengaruh terhadap kemampuan mengatasi masalah pada siswa. Desmita (2005:1) menyatakan bahwa bahwa pola asuh otoriter adalah suatu gaya pengasuhan yang membatasi dan menuntut anak untuk mengikuti 
perintah-perintah orang tua. Z. Idris (1992:87) juga menyatakan bahwa pola asuh otoriter adalah pola asuh yang diterapkan orang tua dengan bercirikan kekuasaan, segala peraturan yang dianut oleh orang tua harus dikerjakan oleh anak dan tidak boleh dibantah.

Selanjutnya Z. Idris (1992:87-88) mengemukakan ciriciri pola asuh otoriter sebagai berikut: (1) anak harus mematuhi peraturan-peraturan orang tua dan tidak boleh membantah; (2) orang tua cenderung mencari kesalahankesalahan pada pihak anak, dan kemungkinan menghukumnya; (3) kalau terdapat perbedaan pendapat antara orang tua dengan anak, maka anak dianggap melawan atau membangkang; (4) orang tua cenderung memberikan perintah dan larangan terhadap anak; (5) orang tua cenderung memaksakan disiplin;

(6) orang tua cenderung menentukan segala sesuatu untuk anak, dan anak hanya sebagai pelaksana.

Perilaku-perilaku orang tua tersebut berperan besar dalam membentuk karakteristik kepribadian anak. Menurut Baldwin (dalam Gerungan, 1998:189) penerapan pola asuh orang tua otoriter akan menghasilkan karakteristik kepribadian yang patuh, pasif, kurang inisiatif, tidak dapat merencanakan sesuatu, daya tahan terhadap stres berkurang dan menjadi anak yang penakut.

Di samping pola asuh orang tua, faktor aktivitas sosial juga sangat berpengaruh. Untuk mengetahui aktivitas sosial seorang individu, dapat dinilai dan interaksi sosial yang dilakukannya sebagaimana yang dinyatakan oleh Samm (2009:1) 
bahwa interaksi sosial merupakan syarat utama terjadinya aktivitasaktivitas sosial.

Menurut Sunaryo (2004:267), interaksi sosial adalah hubungan timbal balik antar individu berupa aksi dan reaksi. Pengertian yang lebih jelas mengenai interaksi sosial dikemukakan oleh M. Sitorus (dalam Sunaryo, 2004:267) sebagai hubungan-hubungan dinamis yang menyangkut hubungan antarindividu dan individu, individu dan kelompok, serta kelompok dan kelompok dalam bentuk kerja sama, persaingan atau pertikaian.

H. Bonner (dalam Sunaryo, 2004:267) menyatakan bahwa "Interaksi sosial adalah suatu hubungan antara dua atau lebih individu manusia, dimana kelakuan individu yang satu memengaruhi, mengubah, atau memperbaiki kelakuan individu yang lain atau sebaliknya".

Soerjono Soekanto (dalam Sunaryo, 2004:268) menyatakan tentang bentuk-bentuk interaksi sosial sebagai berikut: (1) kerja sama, yaitu suatu usaha bersama antara orang per orang atau kelompok manusia untuk mencapai satu atau beberapa tujuan bersama yang dilatar belakangi oleh adanya kepentingan bersama diantara mereka.(2) persaingan, yaitu suatu proses sosial di mana individu atau kelompok manusia yang bersaing, mencari keuntungan melalui bidang kehidupan yang pada suatu masa tertentu menjadi pusat perhatian umum dengan cara menarik perhatian publik atau mempertajam prasangka yang telah ada, (3) pertentangan atau pertikaian, suatu proses sosial dimana individu atau 
kelompok berusaha memenuhi individu yang meliputi kesehatan tujuannya dengan jalan menantang fisik/energi; keterampilan pihak lawan disertai ancaman atau memecahkan masalah; keterampilan kekerasan dan biasanya dilatar sosial; dukungan sosial dan belakangi oleh perbedaan antar ketersediaan sumber daya materi.

individu, perbedaan kebudayaan, Menurut Parker (dalam perbedaan kepentingan dan Fatchiah et.al, 2009:1), faktor utama perubahan social, (4) akomodasi atau dalam mengatasi masalah adalah penyesuaian diri, yaitu proses sosial dukungan sosial dan orang-orang di yang dilakukan individu atau sekitar individu seperti teman, orang kelompok dalam mencapai tua, saudara atau meminta bantuan kestabilan dan keseimbangan pada jasa profesional seperti konselor (equilibrium) antara kepentingan dan atau psikolog.

norma, peraturan, serta hukum yang

Lazarus dan Folkman (dalam berlaku di suatu masyarakat. Dahlia, 2006:48) mengemukakan Akomodasi dapat juga diartikan bahwa faktor-faktor yang sebagai usaha-usaha yang dilakukan untuk meredakan pertentangan tanpa menghancurkan pihak lawan.

Zainun (2002:1) menyatakan menentukan efektivitas mengatasi masalah antara lain: (1) karakteristik kepribadian, yaitu jenis kepribadian dari individu yang bersangkutan; dan bahwa cara individu menangani (3) dukungan sosial, yaitu dukungan situasi yang mengandung tekanan dan bantuan dari orang-orang di ditentukan oleh: sumber daya sekitar individu yang berupa 
informasi untuk membantu individu mengatasi masalahnya maupun dukungan emosional yang memberikan arti bahwa individu merasa dihargai dan diperhatikan.

Mengacu pada beberapa pendapat diatas, penulis berpendapat bahwa faktor-faktor yang mempengaruhi kemampuan mengatasi masalah belajar pada siswa dapat dibedakan menjadi: (1) faktor internal, yang meliputi kesehatan fisik dan psikis, karakteristik kepribadian serta keterampilan dalam berinteraksi dengan orang lain; (2) faktor eksternal, yang meliputi dukungan sosial (keluarga, teman maupun anggota masyarakat yang lebih luas) serta ketersediaan materi (tingkat ekonomi keluarga) yang biasanya merupakan sumber daya berupa uang, barang-barang atau layanan jasa yang dapat dibeli (misalnya konselor / psikolog).

Berdasarkan uraian tersebut, peneliti merumuskan masalah penelitian sebagai berikut:

Adakah pengaruh pola asuh orang tua otoriter terhadap kemampuan mengatasi masalah belajar pada siswa kelas VI SDN Kraton 2 Maospati tahun pelajaran 2010/2011?, (2) Adakah pengaruh tingkat aktivitas sosial siswa terhadap kemampuan mengatasi masalah belajar pada siswa kelas VI SDN Kraton 2 Maospati tahun pelajaran 2010/2011?, (3) Adakah pengaruh dari pola asuh orang tua otoriter dan aktivitas sosial siswa secara simultan terhadap kemampuan mengatasi masalah belajar pada siswa kelas VI SDN Kraton 2 Maospati tahun pelajaran 2010/2011? 


\section{Metode Penelitian}

Penelitian ini dilaksanakan di

SDN Kraton 2 Kecamatan Maospati.

Penentuan lokasi penelitian

ditentukan secara sengaja karena di

SDN Kraton 2 Maospati ini

ditemukan fenomena masalah yang sesuai dengan masalah yang sedang

diteliti peneliti yaitu kemampuan

mengatasi masalah belajar siswa di

sekolah ini sangat rendah, dengan

indikasi banyak siswa yang takut

pulang ke rumah setelah pembagian

hasil ujian, baik ujian tengah

semester maupun ujian akhir

semester.

Penelitian dilaksanakan pada

bulan Januari 2011 sampai dengan

bulan April 20011, dengan subjek

penelitian siswa-siswi kelas VI SDN

Kraton 2 Maospati tahun pelajaran

2010/2011 sejumlah 31 siswa.
Metode yang dipergunakan dalam penelitian ini adalah metode ex-post facto. Metode ini digunakan dengan pertimbangan ada data yang diungkap di dalam diri responden, dan dengan digunakannya metode deskriptif korelasi ex-pos facto peneliti tidak perlu mengungkap data siswa dengan eksperimen khusus. Penggunaan metode deskriptif korelasi ex-post facto ini dipandang cukup mewakili untuk mengetahui ada tidaknya hubungan antara pola asuh orang tua otoriter dan aktivitas sosial siswa terhadap kemampuan siswa dalam mengatasi masalah belajar.

Penelitian ini terdiri dari tiga variabel yaitu pola asuh orang tua otoriter, aktivitas sosial siswa di sekolah dan kemampuan siswa mengatasi masalah belajar. Teknik pengumpulan data ketiga variabel 
tersebut menggunakan teknik angket. Angket yang digunakan dalam penelitian ini adalah angket langsung dan angket tertutup. Disebut sebagai angket langsung karena siswa mengisi sendiri dan sesuai dengan keadaan yang dialaminya dan disebut sebagai angket tertutup karena pertanyaan dalam angket telah diatur oleh peneliti, sehingga responden tinggal memberi tanda pada jawaban yang telah disediakan dalam angket. Dalam penyebaran angket peneliti dibantu oleh salah satu guru ditempat penelitian.

Uji validitas item angket menggunakan teknik statistik dengan rumus korelasi product moment. Uji validitas seperti ini didukung oleh pendapat Suharsimi Arikunto (2002:136) yaitu suatu instrument yang valid atau sahih mempunyai validitas tinggi. Sebaliknya, instrument yang kurang valid berarti memiliki validitas yang rendah.

Data dalam penelitian ini dianalisis dengan menggunakan teknik statistik yaitu menggunakan rumus korelasi berganda. Hasil rhitung kemudian dikonsultasikan dengan r-tabel pada taraf signifikansi 5\%. "Jika r-hitung > r-tabel, maka Ho ditolak dan jika r-hitung $<$ rtabel, maka Ho diterima".

Guna mengetahui signifikansi korelasi variabel-variabel yang dianalisis digunakan rumus korelasi ganda. Hasil F-hitung tersebut dikonsultasikan dengan F-tabel dengan kaidah apabila F-hitung > dari F-tabel maka korelasi tersebut signifikan dan jika F- hitung $<$ Ftabel maka korelasi tersebut tidak signifikan.

\section{Hasil Penelitian}


1. Uji pengaruh pola asuh orang tua otoriter $\left(\mathrm{X}_{1}\right)$ terhadap kemampuan siswa mengatasi masalah belajar (Y).

Hasil perhitungan didapatkan rhitung sebesar -0,908. Setelah dikonsultasikan dengan r-tabel untuk mengetahui signifikan atau tidak signifikan, diketahui untuk $\mathrm{N}=31$, jumlah variabel $=2, \mathrm{r}-$ tabel $=0,355$ pada tingkat kepercayaan $95 \%$ dan $\mathrm{r}$-tabel $=$ 0,456 pada tingkat kepercayaan 99\%, maka r-hitung > r-tabel. Dengan demikian dapat dikatakan bahwa hipotesis penelitian yang menyatakan "ada pengaruh antara pola asuh orang tua otoriter terhadap kemampuan siswa mengatasi masalah belajar" diterima.

2. Uji pengaruh aktivitas sosial siswa $\left(\mathrm{X}_{2}\right)$ terhadap kemampuan siswa mengatasi masalah belajar (Y).

Dari hasil perhitungan didapatkan r-hitung sebesar 0,990. Setelah dikonsultasikan dengan r-tabel untuk mengetahui signifikan atau tidak signifikan, diketahui untuk $\mathrm{N}=31$, jumlah variabel $=2, \mathrm{r}-$ tabel $=0,355$ pada tingkat kepercayaan $95 \%$ dan $\mathrm{r}$-tabel $=$ 0,456 pada tingkat kepercayaan 99\%, maka r-hitung > r-tabel. Dengan demikian dapat dikatakan bahwa hipotesis penelitian yang menyatakan "ada pengaruh antara aktivitas sosial siswa terhadap kemampuan siswa mengatasi masalah belajar" diterima.

3. Uji pengaruh pola asuh orang tua otoriter $\left(\mathrm{X}_{1}\right)$ dan aktivitas sosial siswa $\left(\mathrm{X}_{2}\right)$ terhadap kemampuan siswa mengatasi masalah belajar (Y). Dan hasil perhitungan 
didapatkan r-hitung sebesar 0,948.

Setelah dikonsultasikan dengan rtabel untuk mengetahui signifikan atau tidak signifikan, diketahui untuk $\mathrm{N}=31$, jumlah variabel $=3$, r-tabel $=0,355$ pada tingkat kepercayaan $95 \%$ dan $\mathrm{r}$-tabel $=$ 0,456 pada tingkat kepercayaan 99\%, maka r-hitung > r-tabel. Tingkat signifikansi yang diperoleh mela1ui perhitungan uji-F adalah 112,5 dengan f-label $=3,34$ sehingga F-hitung $>$ Ftabel. Dengan demikian dapat dikatakan bahwa hipotesis penelitian yang menyatakan "ada pengaruh antara pola asuh orang tua otoriter dan aktivitas sosial siswa secara simultan terhadap kemampuan siswa mengatasi masalah belajar" diterima.
Berdasarkan analisis data di atas, maka diperoleh penafsiran data sebagai berikut:

1. Pengaruh pola asuh orang tua otoriter $\quad\left(\mathrm{X}_{1}\right) \quad$ terhadap kemampuan siswa mengatasi masalah belajar (Y).

Berdasarkan hasil penghitungan peneliti, menafsirkan bahwa ada pengaruh yang signifikan dan negatif antara pola asuh orang tua otoriter terhadap kemampuan siswa mengatasi masalah belajar. Dimana semakin tinggi pola asuh orang tua otoriter maka semakin rendah kemampuan siswa mengatasi masalah belajar.

2. Pengaruh aktivitas sosial siswa $\left(\mathrm{X}_{2}\right)$ terhadap kemampuan siswa mengatasi masalah belajar (Y). Berdasarkan hasil penghitungan, peneliti menafsirkan bahwa ada pengaruh yang signifikan dan 
positif antara aktivitas sosial siswa terhadap kemampuan siswa mengatasi masalah belajar.

3. Uji pengaruh pola asuh orang tua otoriter $\left(\mathrm{X}_{1}\right)$ dan aktivitas sosial siswa $\left(\mathrm{X}_{2}\right)$ terhadap kemampuan siswa mengatasi masalah belajar (Y).

Berdasarkan hasil penghitungan, peneliti menafsirkan bahwa ada pengaruh yang signifikan antara pola asuh orang tua otoriter dan aktivitas sosial siswa secara simultan terhadap kemampuan siswa mengatasi masalah belajar dengan kategori pengaruh sangat kuat.

$$
\text { Berdasarkan hasil uji }
$$
hipotesis menggunakan korelasi ganda dari Pearson dan uji signifikansi menggunakan uji-F tersebut dapat disimpulkan bahwa:
1. Ada pengaruh yang signifikan dan negatif antara pola asuh orang tua otoriter terhadap kemampuan siswa mengatasi masalah belajar pada siswa kelas VI SDN Kraton 2 Maospati tahun pelajaran 2010/2011.

2. Ada pengaruh signifikan dan positif antara aktivitas sosial siswa terhadap kemampuan siswa mengatasi masalah belajar pada siswa kelas VI SDN Kraton 2 Maospati tahun pelajaran 2010/2011.

3. Ada pengaruh signifikan dan positif antara pola asuh orang tua otoriter bersama dengan aktivitas sosial siswa secara simultan terhadap kemampuan siswa mengatasi masalah belajar pada siswa kelas VI SDN Kraton 2 Maospati tahun pelajaran 2010/2011. 
Berdasarkan simpulan

hasil penelitian tersebut, maka

peneliti memberikan saran

sebagai berikut:

1. Konselor dan guru hendaknya

saling bekerjasama dalam

memberikan dukungan kepada

siswa yang mengalami masalah

belajar dengan lebih aktif

melakukan pendekatan personal

dan masalah yang dihadapi oleh

siswa dapat dideteksi serta diatasi

sedini mungkin.

2. Siswa diharapkan dapat

meningkatkan kemampuan sosial

dalam berbagai bentuk aktivitas

sosial di lingkungan sekolah

karena hal ini sangat berguna

untuk mengembangkan

kemampuan mengatasi masalah

belajar sehingga dapat mencapai

basil belajar yang maksimal

sesuai dengan potensinya.
3. Orang tua diharapkan lebih memperhatikan kebutuhan putraputrinya sebagai pribadi yang unik dengan menerapkan pola asuh yang luwes namun efektif dalam mendidik putra-putrinya.

\section{Daftar Pustaka}

Ahmad Sudrajat. 2008. Membimbing Kesulitan Belajar Siswa (Online)

http://akhmadsudralat.word press.com/2008/01/25/kesu litan-dan bimbinganbelajar/, diakses tanggal 15 Januari 2011.

Augustine S. Basri. Tanpa tahun. Pola Asuh Efektif: Satukan Komitmen Orangtua (online)

http://www.carisuster.com/ artike1/7-inspired-kids/45pola-asuh-efektif-satukankomitmen-orangtua, diakses tanggal 7 Pebruari 2011.

Dahlia Novarianing Asri. 2006. Kualitas Hidup Penderita Diabetes Melitus Tipe II Ditinjau dari Efikasi Diri, Persepsi Dukungan Sosial dan Strategi Mengatasi Masalah Aktif. Tesis. Yogyakarta: Sekolah Pascasarjana Universitas Gadjah Mada. 
Depdiknas. 2008. Kamus Besar Bahasa Indonesia (Online).

http://pusatbahasa.diknas.g o.id/kbbi/, diakses tanggal 15 Januari 2011.

Dina S. 2007. Perbedaan Kedisiplinan Belajar Siswa Ditinjau dari Pola Asuh Orangtua. Skripsi. Surakarta: $\quad$ Fakultas Psikologi Universitas Muhammadiyah Surakarta.

Endler, Norman S. dan Johnson, Judith M. 2001. Assessment of Coping with Health Problem. Dalam Ad Vingerhoets (Ed). New York:Brunner-Routledge.

Fatchiah E, Haris H. 2009. Pengaruh Strategi Coping terhadap Penyesuaian Din Mahasiswa Baru. Jurnal Universitas Paramadina (Online), Volume 6, No.1,http://jurnal.pdii.lipi. go.id/admin/jurna1/610911 23.pdf, diakses tanggal 16 Jarman 2011.

Gerungan, W.A. 1998. Psikologi Sosial. Bandung: Eresco.

Heri Pranoto. 2010. Takut Tak Lulus, Siswi SMP Gantung Diri (Online)

http://news.okezone.com/re $\mathrm{ad} / 2010 / 05 / 06 / 340 / 330209$ 1340/takut-taklulus-siswistilih-ag -diri.html, diakses tanggal 25 Desember 2010.
Herlin P. 2005. Pola Asuh Orang Tua Dalam Meningkatkan Disiplin Anak di Perumahan Muria Indah Desa Gondangmanis Kecamatan Bae Kabupaten Kudus. Skripsi. Semarang: Fakultas Ilmu Sosial Universitas Negeri Semarang.

Kardi. 2006. Garis-Garis Besar Belajar dan Pembelajaran (Modul Mata Kuliah Belajar dan Pembelajaran). Madiun:IKIP PGRI Madiun.

Miller, George, A. 2010. Wordnet, a Lexical Database for English (Online). http://wordnetweb.princeto n.edu/perl/webwn, diakses tanggal 16 Januari 2011.

M. Sitorus. 1999. Berkenalan dengan Sosiologi 1. Surabaya:Erlangga.

Reina Wangsadjaja. Tanpa Tahun. Konsep Umum: Stress (Online).

http://rumahbelajarpsikolo gi.com/index.php/stres.htm $\underline{1}$, diakses tanggal 9 Januari 2011.

Samm B. 2009. Proses Sosial Dan Interaksi Sosial (Online) http://jurusankomunikasi.bl ogspot.com/2009/04/proses -sosial-dan-interaksisosial.html, diakses tanggal 16 januari 2011. 
St. Vembriarto. 1993. Sosiologi

Pendidikan. Jakarta:

Gramedia.

Sudjana. 1992. Teknik Analisis Regresi dan Korelasi. Bandung: Tarsito.

Suharsimi Arikunto. 1989. Prosedur Penelitian. Yogyakarta: Bina Aksara.

Sumitro. 2007. Pola Asuh Kombinasi

Cara Mendidik Anak Yang Lebih Baik

(Online).http://creasoft.wor dpress.com/2009/02/02/pol a-asuhkombinasi-caramendidik-anak-yang-lebihbaik-2/, diakses tanggal 16 Januari 2011.

Sunaryo, 2004. Psikologi untuk Keperawatan.

Jakarta:EGC.

Sutrisno Hadi. 2000. Statistik 2. Yogyakarta: Andi.

Vitalis D.S. 2008. Landasan Sosial Budaya Bimbingan. Madiun:IKIP PGRI Madiun.

Zainun M. 2002. Strategi

Coping (Online).

http://www.e-

psikologi.com/epsi/individ

ual_detail.asp?id=386,

diakses tanggal 17 Januari 2011.

Z. Idris. 1992. Pengantar Pendidikan

I. Jakarta:Gramedia. 
